\title{
Neisseria gonorrhoeae bacterioferritin: structural heterogeneity, involvement in iron storage and protection against oxidative stress
}

\author{
Cheng-Yen Chen and Stephen A. Morse
}

Division of AIDS, Sexually Transmitted Diseases and Tuberculosis Laboratory Research, National Centers for Infectious Disease, Centers for Disease Control and Prevention, 1600 Clifton Rd, Atlanta, GA 30333, USA
Author for correspondence: Cheng-Yen Chen. Tel: +1 404639 3154. Fax: +1 4046393976. e-mail: cyc1@cdc.gov

The iron-storage protein bacterioferritin (Bfr) from Neisseria gonorrhoeae strain $\mathbf{F 6 2}$ was identified in cell-free extracts and subsequently purified by column chromatography. Gonococcal Bfr had an estimated molecular mass of $400 \mathrm{kDa}$ by gel filtration; however, analysis by SDS-PAGE revealed that it was composed of $18 \mathrm{kDa}$ (BfrA) and $22 \mathrm{kDa}$ (BfrB) subunits. DNA encoding BfrB was amplified by PCR using degenerate primers derived from the $\mathbf{N}$-terminal amino acid sequence of BfrB and from a C-terminal amino acid sequence of Escherichia coli Bfr. The DNA sequence of bfrA was subsequently obtained by genome walking using single-specific-primer PCR. The two Bfr genes were located in tandem with an intervening gap of $27 \mathrm{bp}$. A potential Fur-binding sequence (12 of $19 \mathrm{bp}$ identical to the consensus neisserial fur sequence) was located within the $5^{\prime}$ flanking region of $b f r A$ in front of a putative -35 hexamer. The homology between the DNA sequences of bfrA and bfrB was $55.7 \%$; the deduced amino acid sequences of BfrA (154 residues) and BfrB (157 residues) showed $39.7 \%$ identity, and showed $41.3 \%$ and $56.1 \%$ identity, respectively, to E. coli Bfr. Expression of recombinant BfrA and BfrB in E. coli strain DH5 $\alpha$ was detected on Western blots probed with polyclonal anti-E. coli Bfr antiserum. Most Bfrs are homopolymers with identical subunits; however, the evidence presented here suggests that gonococcal Bfr was composed of two similar but not identical subunits, both of which appear to be required for the formation of a functional Bfr. A Bfr-deficient mutant was constructed by inserting the $\Omega$ fragment into the BfrB gene. The growth of the BfrB-deficient mutant in complex medium was reduced under iron-limited conditions. The BfrB-deficient mutant was also more sensitive to killing by $\mathrm{H}_{2} \mathrm{O}_{2}$ and paraquat than the isogenic parent strain. These results demonstrate that gonococcal Bfr plays an important role in iron storage and protection from iron-mediated oxidative stress.

Keywords: Neisseria gonorrhoeae, iron-storage protein, bacterioferritin

\section{INTRODUCTION}

Iron is important for the growth of bacteria, as evidenced by the wide variety of molecules and mechanisms that have evolved to capture and retain this essential element. However, in the presence of $\mathrm{O}_{2}$, iron is potentially toxic because of its catalytic generation of cell-damaging free

Abbreviations: Bfr, bacterioferritin; DF, Desferal; SSP-PCR, singlespecific-primer PCR.

The GenBank accession numbers for the sequences reported in this paper are U76633 and U76634. radicals (Flitter et al., 1983; Halliwell \& Gutteridge, 1984; Dunford, 1987). To sequester iron for essential requirements and to avoid toxicity from iron overload, aerobic organisms have evolved well-coordinated systems controlling the acquisition, transportation and storage of this element (Briat, 1992).

Two types of iron-storage proteins have been identified in bacteria (Harrison \& Arosio, 1996) : bacterioferritin (Bfr), which contains non-covalently bound haem groups in addition to a non-haem iron core (Stiefel \& Watt, 1979); and ferritin, which does not possess intrinsic haem groups and resembles the iron-containing 
protein (H-type subunit) of mammalian cells (Ford et al., 1984). Bfrs are characteristically composed of 24 identical $18-22 \mathrm{kDa}$ subunits, which are assembled into a spherical protein shell containing $0 \cdot 2-20 \%$ (approx. 600-2400 iron atoms per molecule) by weight of nonhaem iron and 3-12 non-covalently bound protohaem IX groups (Yariv et al., 1981; Ford et al., 1984; Frolow et al., 1994). Subunits are tightly assembled to form a molecule with fourfold, threefold and twofold symmetry axes (432 symmetry) (Ford et al., 1984). Results of electron-microscopic studies have indicated that the iron core can be either crystalline (ferrihydrate) or amorphous. Although the mechanism of iron storage in vivo is uncertain, in vitro, iron-core formation involves the oxidation of $\mathrm{Fe}(\mathrm{II})$ and hydrolytic polymerization of $\mathrm{Fe}(\mathrm{III})$ (Andrews et al., 1993; Hudson et al., 1993).

Studies on Neisseria gonorrhoeae have focused primarily on the receptor-mediated mechanisms that this organism uses to obtain iron from host sources; very little is known about the fate of intracellular iron. In this study, we report the identification and purification of a Bfr from N. gonorrhoeae composed of two non-identical subunits; the genes encoding these subunits have been cloned and sequenced. A BfrB-deficient mutant was constructed to examine the biological role of gonococcal Bfr.

\section{METHODS}

Organisms and growth conditions. N. gonorrhoeae strain F62 was used for purification of Bfr. This strain was maintained on GC agar (Difco Laboratories) supplemented with 1\% (v/v) IsoVitaleX (Baltimore Biological Laboratories). To determine the effect of iron limitation on the growth of a gonococcal BfrB-deficient mutant, cells were grown in GC broth (Mietzner et al., 1984) supplemented with $1 \%$ IsoVitaleX, $0.04 \%$ (w/v) $\mathrm{NaHCO}_{3}$, and with or without $30 \mu \mathrm{M}$ Desferal (DF) (CibaGeigy). Broth cultures were incubated at $37^{\circ} \mathrm{C}$ in a gyratory shaker and growth was followed for $8 \mathrm{~h}$ by monitoring the optical density of the culture at $600 \mathrm{~nm}$ in a model DU-70 spectrophotometer (Beckman Instruments). Escherichia coli strain DH5 $\alpha$ was used as a host for recombinant plasmids and was grown on Luria broth (LB) agar. The $\Omega$ fragment was purified from E. coli strain HB101 containing pHP45 $\Omega$. This was accomplished by purifying $\mathrm{pHP} 45 \Omega$ with a plasmid midikit (Qiagen), digesting the plasmid with HindIII and then by gel purifiying the $2 \mathrm{~kb}$ DNA band containing the $\Omega$ fragment. All cultures were grown at $37^{\circ} \mathrm{C}$ in a humidified atmosphere containing $5 \% \mathrm{CO}_{2}$. pUC18 was purchased from Bethesda Research Laboratories.

Purification of gonococcal Bfr. Overnight growth of $N$. gonorrhoeae strain F62 was harvested from GC agar plates and resuspended in $20 \mathrm{mM}$ Tris/ $\mathrm{HCl}$ buffer $(\mathrm{pH} 7 \cdot 2)$. The cell suspension was sonicated ( $30 \mathrm{~s}, 6$ times) and then centrifuged at $10000 \mathrm{~g}$ for $20 \mathrm{~min}$. The supernatant was decanted, heated to $65-70{ }^{\circ} \mathrm{C}$ for $15 \mathrm{~min}$ and centrifuged at $10000 \mathrm{~g}$ for $20 \mathrm{~min}$. The heat-treated supernatant was then fractionated by precipitation with $\left(\mathrm{NH}_{4}\right)_{2} \mathrm{SO}_{4}$. The fraction that precipitated between 30 and $60 \%$ saturation was collected by centrifugation $(10000 \mathrm{~g}, 15 \mathrm{~min})$, dissolved in $20 \mathrm{mM}$ Tris/ $\mathrm{HCl}$ buffer ( $\mathrm{pH} 7.2)$ and desalted by dialysis against the same buffer overnight at $4{ }^{\circ} \mathrm{C}$. The dialysed material was applied to a Sephacryl S-200-HR (Sigma) gel-filtration column $(0 \cdot 9 \times 60 \mathrm{~cm})$ that had been equilibrated with $20 \mathrm{mM}$ Tris/
$\mathrm{HCl}$ buffer ( $\mathrm{pH} 7 \cdot 4)$ containing $0 \cdot 15 \mathrm{M} \mathrm{NaCl}$. The molecular mass standards (Bio-Rad) used were thyroglobulin $(670 \mathrm{kDa})$, bovine gamma globulin $(158 \mathrm{kDa})$, chicken ovalbumin $(44 \mathrm{kDa})$, equine myoglobin $(17 \mathrm{kDa})$ and vitamin $\mathrm{B}_{12}$ $(1.35 \mathrm{kDa})$. The iron-stain-positive fractions, corresponding to $300-500 \mathrm{kDa}$ molecular mass, were pooled and concentrated by centrifugation (Centriprep-30; Amicon). The retentate was dialysed overnight against $20 \mathrm{mM}$ Tris/ $\mathrm{HCl}$ buffer $(\mathrm{pH} \mathrm{7 \cdot 2)}$ and then fractionated by anion-exchange chromatography using a DEAE Sepharose CL-6B (Sigma) column $(2 \cdot 8 \times 11 \mathrm{~cm})$. Proteins were eluted with a linear gradient of $0 \cdot 1-0 \cdot 6 \mathrm{M} \mathrm{NaCl}$; Bfr eluted at approximately $0 \cdot 3 \mathrm{M} \mathrm{NaCl}$. The purity of Bfr was assessed by SDS-PAGE and by iron-specific staining of non-denaturing polyacrylamide gels.

Iron-specific stain. After electrophoresis of cell-free extracts in non-denaturing polyacrylamide gels, iron-containing proteins were visualized by staining with a solution of $0.75 \mathrm{mM} \mathrm{3-(2-}$ pyridyl)-5,6-bis(4-phenylsulfonic acid)-1,2,4-triazine, sodium salt (Ferrozine; Sigma) and $15 \mathrm{mM}$ thioglycolic acid in $2 \%$ (v/v) acetic acid (Chung, 1985). To locate column fractions containing iron, an aliquot of each column fraction $(200 \mu \mathrm{l})$ was added to the Ferrozine reagent $(5 \mu \mathrm{l})$ and the absorbance at $562 \mathrm{~nm}$ was measured after $15 \mathrm{~min}$. Iron-containing protein bands or column fractions exhibited a visible red colour within $20 \mathrm{~min}$ of staining. The iron-stained gel was subsequently stained with Coomassie blue and destained with $10 \%$ $(\mathrm{v} / \mathrm{v})$ acetic acid in order to visualize the presence of any other cellular proteins.

$\mathrm{N}$-terminal sequence analysis. Purified Bfr was subjected to SDS-PAGE and electro-transferred onto a PVDF membrane (Schleicher \& Schuell). Protein bands were excised from the transblot and sequenced by standard Edman chemistry on a Beckman PI2090 Integrated Micro-sequencing System.

PCR and DNA sequence analysis. $b f r B$ was PCR-amplified using a forward degenerate primer (964FP, Table 1), deduced from the $\mathrm{N}$-terminal amino acid sequence of gonococcal $\mathrm{BfrB}$, and a reverse degenerate primer (966RP, Table 1), based on a conserved region in the C-terminal of the E. coli Bfr (amino acids 128-134) (Andrews et al., 1989; Denoel et al., 1995). PCR conditions consisted of 30 cycles of denaturation at $94{ }^{\circ} \mathrm{C}$ for $1.5 \mathrm{~min}$, annealing at $62^{\circ} \mathrm{C}$ for $2 \mathrm{~min}$ and extension at $72^{\circ} \mathrm{C}$ for $2 \mathrm{~min}$. The flanking regions and the remaining sequences of gonococcal $b f r A$ and $b f r B$ were completed by using single-specific-primer PCR (SSP-PCR) (Shyamala \& Ames, 1989). The Applied Biosystems model 373 DNA sequencing system (Perkin-Elmer) was used for sequencing the PCR products according to the manufacturer's cycle sequencing protocol by using dye-terminator chemistry (Sanger et al., 1977).

Cloning of Bfr genes. The entire $b f r A$ and $b f r B$ coding sequences were amplified by PCR using synthetic primers designed to introduce an EcoRI restriction site at the start codon (FPEco1, Table 1) and a BamHI site just downstream of the stop codon (RPBam1, Table 1). The PCR product was double-digested with BamHI and EcoRI and ligated into pUC18. Competent E. coli DH5 $\alpha$ cells were transformed and ampicillin-resistant transformants selected on LB medium containing $50 \mu \mathrm{g}$ ampicillin $\mathrm{ml}^{-1}$. Plasmid minipreps from several transformants were prepared and sequenced to confirm that the $b f r$ sequence was correct and in-frame with lacZ. The recombinant plasmid in one of the transformants was selected and designated pCYC-1.

Expression of gonococcal Bfr. Whole-cell lysates prepared from E. coli DH $5 \alpha$, DH $5 \alpha$ with pUC18, or DH $5 \alpha$ with pCYC1 were fractionated by SDS-PAGE and electro-transferred 
Table 1. Primer sequences of oligonucleotides used in this study

\begin{tabular}{|c|c|c|}
\hline $\begin{array}{l}\text { Primer } \\
\text { designation }\end{array}$ & Sequence* & Use \\
\hline 964FP & GTIATICGIGAACTIAACAAAAA & Amplification of $b f r B$ \\
\hline 966RP & CCAITCIATITGICCITCITC & Same as above \\
\hline FPEco1 & CCCGAATTCATGCAAGGCAATCAAGCTGTT & $\begin{array}{l}\text { Amplification of } b f r A \text { and } \\
b f r B\end{array}$ \\
\hline RPBam1 & CCCGGATCCGTCCTCTTGCGCCGCTGTTTG & Same as above \\
\hline FPEco 2 & CCCAATTCCACCGTTTGCGAGGAAGCCTC & $\begin{array}{l}\text { Amplification of } b f r A \text { and } \\
b f_{r} B \text { and flanking regions }\end{array}$ \\
\hline RPBam2 & CCCGGATCCCATATCGGTATTATCAAACAA & Same as above \\
\hline
\end{tabular}

*I represents inosine.

onto a nitrocellulose membrane (Schleicher \& Schuell). The blot was probed with anti-E. coli Bfr polyclonal antiserum $(1: 1000)$ and bound antibody detected with horseradishperoxidase-labelled goat anti-rabbit IgG conjugate (Bio-Rad).

Construction of a BfrB-deficient mutant of $\boldsymbol{N}$. gonorrhoeae. The sequence encompassing $b f r A$ and $b f r B$ and their corresponding flanking regions were amplified by PCR using synthetic oligonucleotide primers (FPEco2 and RPBam2, Table 1) designed to introduce an EcoRI restriction site $1.1 \mathrm{~kb}$ upstream of the start codon of $b f r A$ and a $B a m H I$ site $163 \mathrm{bp}$ downstream of the stop codon of $b f r B$. The resulting $2 \cdot 4 \mathrm{~kb}$ PCR fragment was double-digested with BamHI and EcoRI and ligated into pUC18. The single HindIII restriction site on pUC18 had been previously eliminated by digesting with the enzyme, end-filled using the Klenow fragment and religated. Competent E. coli DH5 $\alpha$ cells were subsequently used for transformation. Ampicillin-resistant transformants were obtained on LB medium containing $50 \mu \mathrm{g}$ ampicillin $\mathrm{ml}^{-1}$. Plasmid minipreps were prepared to confirm the presence of the $2.4 \mathrm{~kb}$ DNA insert. The recombinant plasmid, designated pCYC-2, was digested with HindIII, which cuts only once in the coding region of $b f_{r} B$, and ligated with the purified $\Omega$ fragment prepared with HindIII ends. Competent E. coli DH5 $\alpha$ cells were transformed as previously described and transformants selected on LB medium containing $30 \mu \mathrm{g}$ ampicillin $\mathrm{ml}^{-1}$ and $30 \mu \mathrm{g}$ spectinomycin $\mathrm{ml}^{-1}$. The pCYC-2 containing the insertionally inactivated $b f r B$, designated pCYC-3, was purified from several transformants to confirm the insertion of the $\Omega$ fragment and then linearized with EcoRI prior to transforming piliated cells of $N$. gonorrhoeae strain F62. Gonococcal transformants were selected on GC agar plates containing $30 \mu \mathrm{g}$ streptomycin $\mathrm{ml}^{-1}$ and $30 \mu \mathrm{g}$ spectinomycin $\mathrm{ml}^{-1}$. The presence of the $\Omega$ fragment in $b f r B$ was confirmed by PCR amplification of the BfrB structural gene. One of the transformants, designated $\mathrm{F} 62 \mathrm{BfrB} \Omega$, was selected for further studies.

Sensitivity to $\mathrm{H}_{2} \mathbf{O}_{2}$ and paraquat. The sensitivity of $N$. gonorrhoeae strain $\mathrm{F} 62$ and its isogenic BfrB-deficient mutant to $\mathrm{H}_{2} \mathrm{O}_{2}$ and paraquat was determined by a disc-diffusion assay. Gonococci were grown overnight on GC agar plates and resuspended in GC broth to a concentration of $10^{8}$ c.f.u $\mathrm{ml}^{-1}$ and $100 \mu \mathrm{l}$ of the cell suspension was spread onto GC agar plates. Filter paper discs $(1 / 4$ in. in diameter, Schleicher \& Schuell), containing various amounts of $\mathrm{H}_{2} \mathrm{O}_{2}(0-5 \mu \mathrm{mol})$ or paraquat $(0-3 \mu \mathrm{mol})$, were placed on the surface of the plate. After $24 \mathrm{~h}$ incubation at $35^{\circ} \mathrm{C}$ with $5 \% \mathrm{CO}_{2}$, plates were examined for zones of growth inhibition. The zone of growth inhibition was determined by measuring the diameter $(\mathrm{cm})$ of the clear zone surrounding the disc minus the diameter of the disc. The mean zone of inhibition \pm standard deviation was calculated from the results of three separate experiments.

\section{RESULTS}

\section{Purification of gonococcal Bfr}

Bfr was initially purified by size-exclusion chromatography and its location identified by the addition of Ferrozine to each column fraction and monitoring of OD at $562 \mathrm{~nm}$. Bfr-containing fractions exhibited the highest $\mathrm{OD}_{562}$ and were subjected to non-denaturing PAGE followed by the iron-specific stain. Subsequent staining of the same gel with Coomassie blue revealed the presence of several protein-containing bands; however, Bfr was the only protein that could be visualized by the iron-specific stain. The molecular mass of Bfr, as estimated by gel filtration, was between 300 and $500 \mathrm{kDa}$. DEAE-Sepharose column chromatography was subsequently used for further purification of Bfr. Fractions eluted by a $\mathrm{NaCl}$ gradient, which exhibited the highest OD at $562 \mathrm{~nm}$ in the presence of Ferrozine, were assessed by SDS-PAGE (12\% acrylamide) and Coomassie blue staining. The data in Fig. 1 show that, without heating, purifed Bfr migrated as a single proteincontaining band at a slower rate than the $97 \mathrm{kDa}$ molecular mass standard (lane 1). However, after heating at $100{ }^{\circ} \mathrm{C}$ for $10 \mathrm{~min}$ in sample loading buffer, Bfr migrated as two smaller bands with estimated molecular masses of 18 and $22 \mathrm{kDa}$, respectively (lane 2, shown with arrows). It was noted that after heating and electrophoresis, Bfr could not be visualized by the ironspecific stain (data not shown).

\section{$\mathrm{N}$-terminal sequence analysis}

The bands containing the 18 and $22 \mathrm{kDa}$ proteins were eluted from the gels and the sequence of the first 10 (MQGNQAVVDY) N-terminal residues of the $18 \mathrm{kDa}$ protein and the first 15 (MKGDRLVIRELNKNL) Nterminal residues of the $22 \mathrm{kDa}$ protein were obtained by automated Edman degradation. These $\mathrm{N}$-terminal sequences showed similarities $(30-66 \%)$ to the $\mathrm{N}$ - 
1

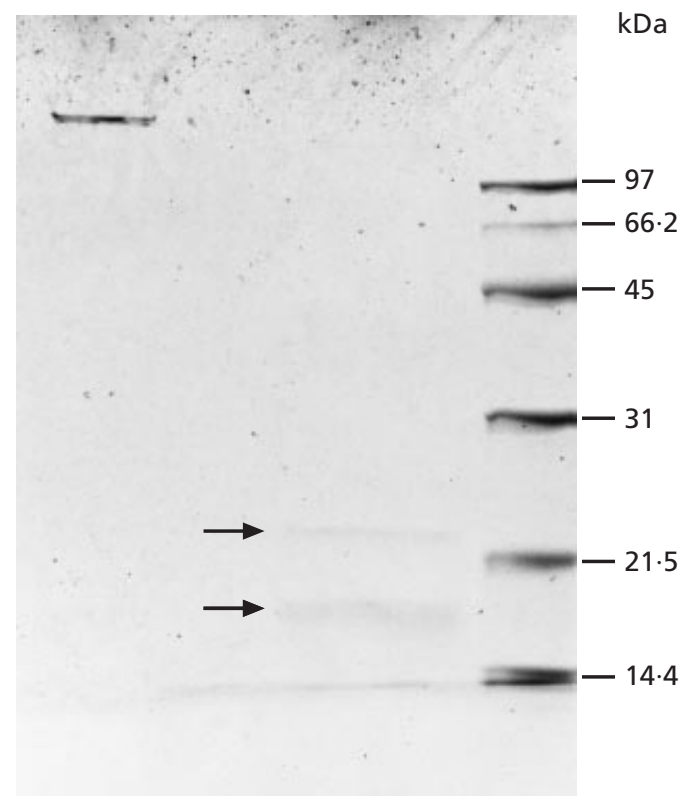

Fig. 1. Coomassie blue-stained SDS-PAGE (12\% acrylamide) of the multimeric (lane 1) and monomeric (lane 2) forms of $N$. gonorrhoeae Bfr. Lanes: 1, purified Bfr without heating at $100^{\circ} \mathrm{C}$; 2, purified $\mathrm{Bfr}$ heated at $100^{\circ} \mathrm{C}$ for $10 \mathrm{~min}$ in sample loading buffer. Arrows indicate band sizes mentioned in the text.

terminal sequences of several bacterial Bfrs, for example E. coli, Nitrobacter winogradskyi, Azotobacter vinelandii, Brucella melitensis, Synechocystis spp., Mycobacterium leprae, Mycobacterium paratuberculosis and Mycobacterium avium, and were designated as BfrA (18 kDa) and BfrB (22 kDa).

\section{PCR and DNA sequence analysis}

Degenerate primers deduced from the $\mathrm{N}$-terminal amino acid sequence of the gonococcal $\mathrm{BfrB}$ and from a region of E. coli Bfr (amino acids 128-134) were used to PCRamplify the majority of the BfrB gene. The flanking regions and the remaining sequence of the BfrB gene were obtained by SSP-PCR. Results of this additional sequencing indicated that the DNA sequence encoding $b f r A$ was upstream of $b f r B$. The complete nucleotide and deduced amino acid sequences of the gonococcal Bfrs indicated two ORFs of $462 \mathrm{bp}$ and $471 \mathrm{bp}$, corresponding to positions $148-609$ and $640-1110$, respectively. The two Brf genes were located in tandem with an intervening gap of 27 bases. Potential ShineDalgarno ribosome-binding sites (GAGAG for $b f r A$ and AGGAG for $b f r B$ ) were located 6-10 bp upstream from the ATG start codon of $b f_{r} A$ and $b f_{r} B$, respectively. Putative -10 and -35 promoter regions were also identified and a GC-rich region of dyad symmetry located 43 bp downstream from the stop codon in $b f_{r} B$ could function as a rho-independent transcription terminator. There was a potential Fur-binding sequence (12 of 19 bases were identical to the consensus neisserial
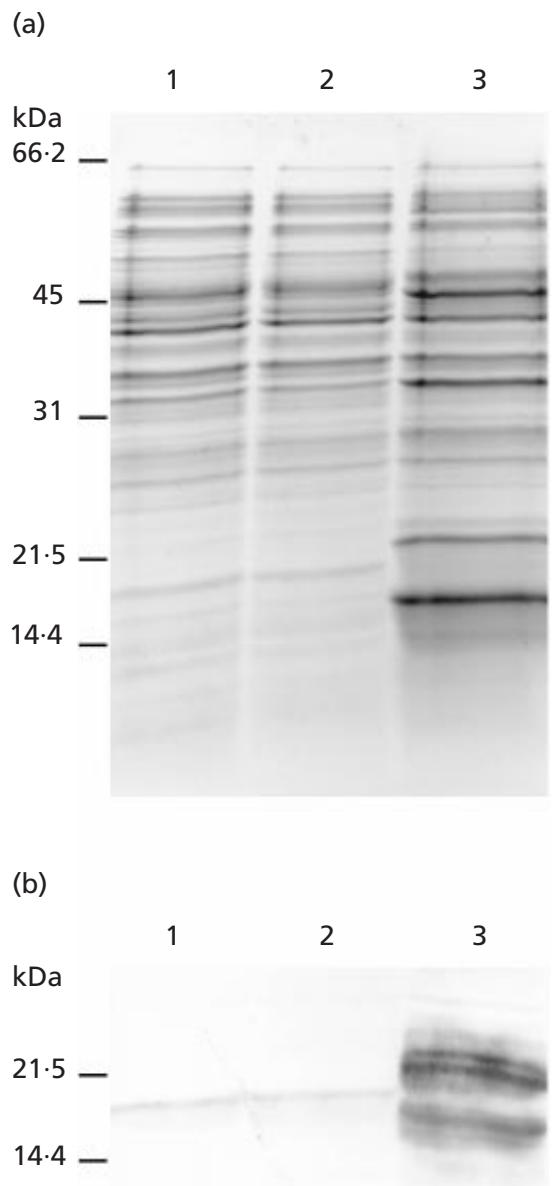

Fig. 2. Expression of gonococcal Bfr in E. coli $\mathrm{DH} 5 \alpha$. Whole-cell lysates from $\mathrm{DH} 5 \alpha$ with or without gonococcal Brf were separated by SDS-PAGE (a), electro-transferred and probed with anti-E. coli Bfr polyclonal antiserum (b). Lanes: $1, \operatorname{DH} 5 \alpha ; 2$, DH5 $\alpha$ with pUC18; 3, DH5 $\alpha$ alone with pCYC-1.

fur sequences; Genco \& Desai, 1996) in front of the -35 hexamer. There was $55.7 \%$ homology between the DNA sequences of $b f r A$ and $b f r B$; and $39.7 \%$ identity for the amino acid sequences of BfrA and BfrB. The deduced amino acid sequence of BfrA consisted of 154 amino acids with a predicted molecular mass of $17961 \mathrm{Da}$ and an isoelectric point (pI) of 4.57; BfrB consisted of 157 amino acids, and had a molecular mass of $18014 \mathrm{Da}$ and a pI of $4 \cdot 58$. The deduced amino acid sequences of BfrA and BfrB showed $41.3 \%$ and $56 \cdot 1 \%$ identity to E. coli Bfr, respectively.

\section{Cloning and expression of Bfr}

The entire coding sequence encompassing $b f r A$ and $b f r B$ was amplified by PCR and ligated into pUC18 and inframe with lacZ. Competent E. coli DH5 $\alpha$ cells were 


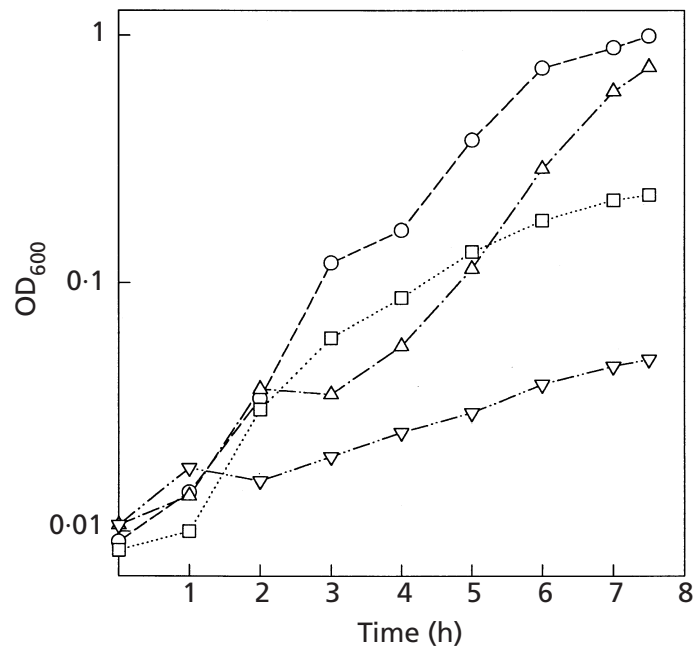

Fig. 3. Effect of iron limitation on the growth of $N$. gonorrhoeae strain F62 and Bfr-deficient strain F62BfrB $\Omega$. Cells were grown in GC broth supplemented with IsoVitaleX and with or without $30 \mu \mathrm{M}$ DF. Broth cultures were incubated at $37^{\circ} \mathrm{C}$ in a gyratory shaker and the growth was monitored by measuring $\mathrm{OD}_{600}$ over a period of $8 \mathrm{~h}$. $\mathrm{O}, \mathrm{F} 62+\mathrm{Fe} ; \triangle, \mathrm{F} 62 \mathrm{BfrB} \Omega$ $+\mathrm{Fe} ; \square, \mathrm{F} 62+\mathrm{DF} ; \nabla, \mathrm{F} 62 \mathrm{BfrB} \Omega+\mathrm{DF}$.

transformed, and transformants containing pCYC-1 were analysed for expression of gonococcal Bfr on Western blots probed with anti-E. coli Bfr polyclonal antiserum. The results in Fig. 2 show that E. coli DH5 $\alpha$ or E. coli $\mathrm{DH} 5 \alpha$ containing pUC18 exhibited a single Bfr subunit of $20 \mathrm{kDa}$. The transformants expressed two additional proteins corresponding in size to the gonococcal BfrA and B (Fig. 2a, lane 3), and both proteins reacted with the polyclonal antiserum to E. coli Bfr (Fig. $2 \mathrm{~b}$, lane 3$)$. These additional proteins were not observed in E. coli $\mathrm{DH} 5 \alpha$ or E. coli $\mathrm{DH} 5 \alpha$ containing pUC18.

\section{Construction of a BfrB-deficient mutant of N. gonorrhoeae}

A BfrB-deficient mutant was constructed to determine the biological function of gonococcal Bfr. Attempts to construct a gonococcal BfrA-deficient mutant, or a double knock out by either insertion or deletion inactivation were not successful because of the lack of restriction sites in $b f r A$. Therefore, pCYC-2 was disrupted by the insertion of the $\Omega$ fragment from pHP $45 \Omega$ into the single HindIII site present in $b f r B$. The resulting plasmid, pCYC-3, which contains the insertionally inactivated $b f r B$, was linearized with EcoRI prior to transforming piliated N. gonorrhoeae strain F62. One of the several spectinomycin- and streptomycin-resistant transformants, $\mathrm{F} 62 \mathrm{BfrB} \Omega$, was selected for further studies. The presence of the $\Omega$ fragment in the BfrB gene of $\mathrm{F} 62 \mathrm{BfrB} \Omega$ was confirmed by PCR amplification of $b f_{r} A$ and $b f_{r} B$ individually. The $b f r A$ amplicon from $\mathrm{F} 62 \mathrm{BfrB} \Omega$ was the same size as that from strain $\mathrm{F} 62$; however, the $b f r B$ amplicon from $\mathrm{F} 62 \mathrm{BfrB} \Omega$ was $2 \mathrm{~kb}$ larger than that of strain F62, indicating that the $\Omega$

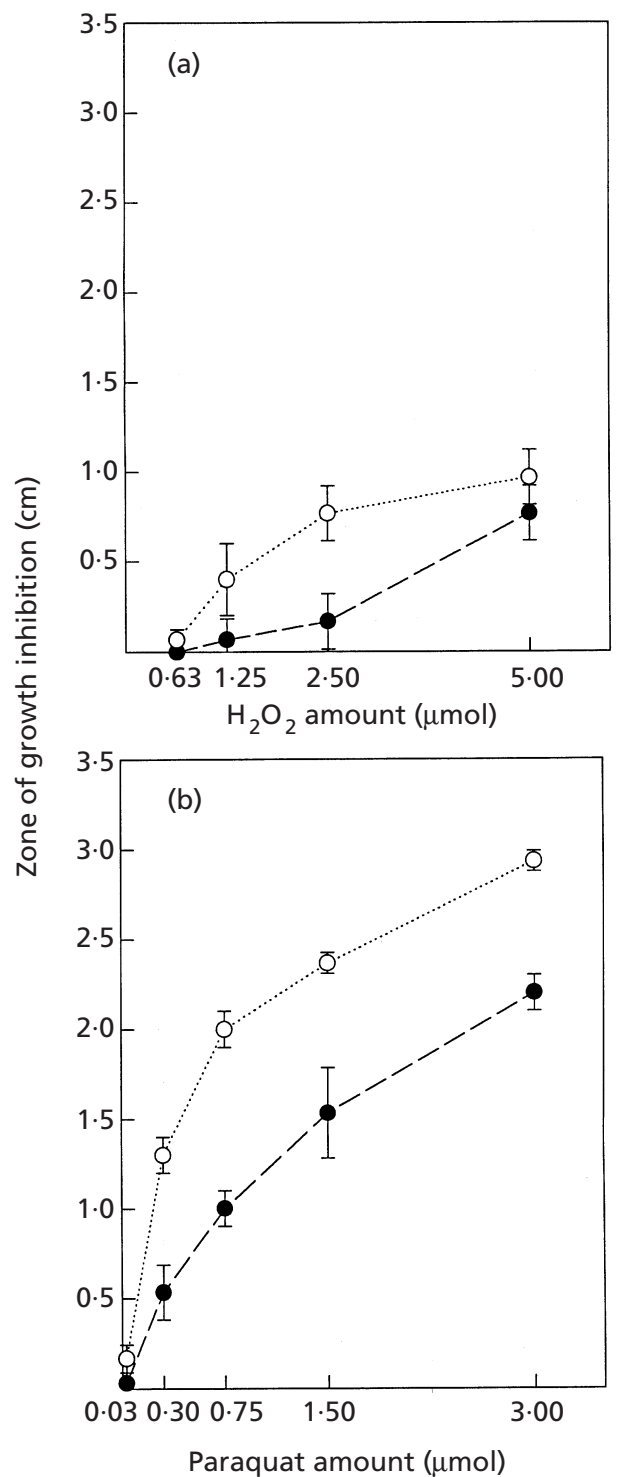

Fig. 4. Sensitivity of $N$. gonorrhoeae BfrB-deficient mutant to $\mathrm{H}_{2} \mathrm{O}_{2}$ and paraquat. The disc-diffusion assays were conducted on GC agar plates as described in Methods. Various amounts of $\mathrm{H}_{2} \mathrm{O}_{2}$ or paraquat were placed on the filter-paper discs. The zone of growth inhibition was determined by measuring the diameter of the clear zone surrounding the disc minus the diameter of the disc. Data shown are the mean and standard deviation from three separate experiments. O, Strain F62; O, Bfr-deficient strain $\mathrm{F} 62 \mathrm{Bfr} B \Omega$.

fragment was inserted into $b f_{r} B$ (data not shown). The absence of BfrB subunits in the mutant was also confirmed by immunoblot analysis with anti-E. coli Bfr antiserum (data not shown).

\section{Effect of iron on the growth of BfrB-deficient mutant}

$N$. gonorrhoeae strains $\mathrm{F} 62$ and $\mathrm{F} 62 \mathrm{Bfr} \mathrm{B} \Omega$ were grown in liquid GC medium with or without $30 \mu \mathrm{M}$ DF. Growth of both strains was markedly reduced under iron-limited conditions (Fig. 3); however, growth of 
strain $\mathrm{F} 62 \mathrm{BfrB} \Omega$ was inhibited to a greater degree than was the growth of strain F62 under identical growth conditions.

\section{Sensitivity of BfrB-deficient mutant to $\mathrm{H}_{2} \mathrm{O}_{2}$ and paraquat}

To assess the contribution of BfrB to the oxidative stress resistance of $N$. gonorrhoeae, the sensitivities of strains $\mathrm{F} 62$ and $\mathrm{F} 62 \mathrm{BfrB} \Omega$ to $\mathrm{H}_{2} \mathrm{O}_{2}$ and paraquat were compared in a disc-diffusion assay. The results (Fig. 4a) show that the growth of $\mathrm{F} 62 \mathrm{BfrB} \Omega$ was inhibited by $\mathrm{H}_{2} \mathrm{O}_{2}$ in a dose-dependent fashion, whereas the growth of wild-type parent strain was inhibited to a lesser degree by amounts of $\mathrm{H}_{2} \mathrm{O}_{2}$ up to $2.5 \mu \mathrm{mol}$; both F62 and $\mathrm{F} 62 \mathrm{BfrB} \Omega$ exhibited a similar growth inhibition at $5 \mu \mathrm{mol} \mathrm{H}_{2} \mathrm{O}_{2}$. Paraquat is a redox-cycling agent that readily diffuses across the cell envelopes and generates superoxide within the cytosol. Both strains F62 and $\mathrm{F} 62 \mathrm{Bfr} \mathrm{B} \Omega$ appeared to be more sensitive to inhibition by paraquat than $\mathrm{H}_{2} \mathrm{O}_{2}$ and the growth of $\mathrm{F} 62 \mathrm{BfrB} \Omega$ was inhibited to a greater extent than strain $\mathrm{F} 62$ even at the lowest concentration of paraquat tested (Fig. 4b).

\section{DISCUSSION}

Iron is an essential element for the growth of almost all bacteria. Many of the molecular details of iron assimilation have been explored (Briat, 1992; Wooldridge \& Williams, 1993); however, most of these studies have focused on the variety of strategies that bacterial pathogens employ to obtain iron from the host. Relatively little attention has been given to the intracellular sequestration, mobilization and storage of iron. Under aerobic conditions, excess iron may contribute to the generation of compounds by stimulating the production of highly reactive oxygen species by the iron-catalysed Haber-Weiss reaction (Haber \& Weiss, 1934). The resulting hydroxyl radicals can cause lipid peroxidation, DNA damage and degradation of other biomolecules (Halliwell \& Gutteridge, 1984; Touati et al., 1995). Thus, strict regulation of assimilation and storage of iron in both eukaryotic and prokaryotic cells is crucial to prevent the accumulation of free intracellular iron and to protect cells from iron toxicity (Klausner et al., 1993). Protection from iron toxicity may be mediated, in part, by ferritins and Bfr, which are capable of sequestering a few thousand iron atoms in their central cavity in a soluble, non-toxic, bioavailable form (Grossman et al., 1992).

In this study, we have identified and purified a Bfr from $N$. gonorrhoeae, and subsequently cloned and sequenced the corresponding genes. The identification of gonococcal Bfr was facilitated by an iron-specific stain, which is based on the interaction between the iron atoms stored in the Bfr and a sensitive chromogenic ligand, Ferrozine, which results in the formation of a reddish-coloured complex. Bfr was the only protein in non-denaturing PAGE of supernatants of sonicated cell suspensions that could be readily stained with Ferrozine, indicating the high content of iron molecules within this protein. Additional data indicating that this protein is Bfr include heat stability $\left(65-70{ }^{\circ} \mathrm{C}\right.$ for $15 \mathrm{~min}$ ) (Smith et al., 1988; Andrews et al., 1993), molecular mass between 300 and $500 \mathrm{kDa}$ for the holoprotein and between 18 and $22 \mathrm{kDa}$ for its subunits, N-terminal sequence homology to Bfr subunits from other bacteria, and immunological cross-reactivity with anti-E. coli Bfr antiserum.

Unlike most Bfrs, which are homopolymers composed of identical subunits, gonococcal Bfr comprises two similar, but not identical, subunits. Harker \& Wullstein (1985) reported that the Bfr from A. vinelandii comprised two non-identical subunits; however, Grossman et al. (1992) were able to clone only one gene for this protein. More convincing data for structural heterogeneity of $\mathrm{Bfr}$ were obtained from Pseudomonas aeruginos $a$, in which the first 69 and 55 residues of the N-terminal amino acid sequence of the $\alpha$ and $\beta$ subunits differed considerably (Moore et al., 1994). The corresponding genes for the $\alpha$ and $\beta$ subunits of $P$. aeruginosa Bfr have not been cloned to further substantiate these findings. The results of our study are the first to locate genes encoding different Bfr subunits and verify the existence of structural heterogeneity in this iron-storage protein. Structural heterogeneity of $\mathrm{Bfr}$ may be less complicated than in mammalian ferritins, where the structural complexity is due to combinations of various ratios of two subunits, heavy $(\mathrm{H})$ and light (L), which differ in size, amino acid composition, surface charge and immunoreactivity (Theil, 1987; Harrison \& Arosio, 1996).

How the biosynthesis of Bfr or prokaryotic ferritin is regulated by iron awaits elucidation. In E. coli, the induction of $b f r$ expression by iron was found to be dependent on the ferric uptake regulator protein (Fur), although not to the direct interaction between Fur and the $b f r$ gene (Harrison \& Arosio, 1996). It is not clear how Fur acts as an intermediate and what other cellular components are involved in this regulation. The genes encoding the two gonococcal Bfr subunits were located in tandem with an intervening gap of only $27 \mathrm{bp}$, suggesting that they might be co-transcribed and coregulated. The presence of a potential iron box within the $5^{\prime}$ region of $b f r A$ in front of a putative -35 hexamer suggests that gonococcal Bfr might be negatively regulated by iron. However, this contradicts results obtained with other micro-organisms, suggesting that in spite of the presence of potential iron boxes the production of Bfr was either up-regulated by, or indifferent to, the iron concentration present in the growth medium (Grossman et al., 1992; Cristina et al., 1994; Evans et al., 1995). The genetic regulation of gonococcal $\mathrm{Bfr}$ is currently under investigation.

Despite the structural similarity between ferritins and Bfrs, they share little homology in their amino acid sequences and exhibit no immunological cross-reactivity (Wai et al., 1995), suggesting that they have different origins. Most studies suggest micro-organisms possess 
$1 \quad \bullet \quad \bullet \quad 50$ NGBFIA MQGNQAVVDY MNELLSGELA ARDQYFIHSR LYSEWGYTKL FERLNHEMEE SYBfr MKGKPAVLAQ LHKLLRGELA ARDQYFIHSR MYQDWGLEKL YSRIDHEMQD AvBfr MKGDKIVIQH LNKILGNELI AINQYFLHAR MYEDWGLEKL GKHEYHESID ECBfr MKGDTKVINY LNKLLGNELV AINQYFLHAR MFKNWGLKRL NDVEYHESID NGBfrB MKGDRLVIRE LNKNLGLLLV TINQYFLHAR ILKNWGFEEL GEHFFKOSIV MIBfr MOGDPDVLRL LNEQLTSELT AINOYFLHSK MQENWGFTEL AERTRVESFD MPBfr MOQDPEVIRL INEQTSELT AINOYFLHSK MODNWGFTEL AE ....... MPBST MQGDPEVLRL LNEQLTSELT AINQYFLHSK MQDNWGFTEL AE.......... MQGDPEVLRL LNEQLTTQLT AINQYFLHSK MQDNWGFTEL AEHTRAESF $\begin{array}{lll}\text { NWBfr } & \text { MKGDPKVIDY LNKALRHELT AINQYWLHYR } & \text { LLDNWGIKDL AKKWRAESIE } \\ \text { BmBfr } & \text { MKGEPKVIER LNDALFLELG AVNOYWLHYR LLNDWGYTRL AKKEREESIE }\end{array}$ $51 \bullet r$ • 100 NgBfrA ETTHAEDFIR RILMLGGTPK MAR.AELNIG TDVVCLKAD LQTEYEVRDA

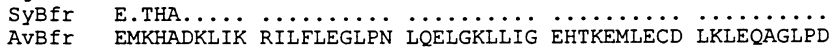
$\begin{array}{ll}\text { AvBfr } & \text { EMKHADKLIK RILFLEGLPN LQELGKLLIG EHTKEMLECD LKLEQAGLPD } \\ \text { ECBfr } & \text { EMKHADRYIE RILFLEGLPN LQDLGKLNIG EDVEMLRSD LALELDGAKN }\end{array}$ NgBfrB EMKAADDLIE RILFLEGLPN LOELGKLLIG ESTEEIIACD LTKEQEKHEA MIBfr EMRHAEAITD RILLLDGLPN YQRIGSLRVG QTLREQFEAD LAIEYEVMSR

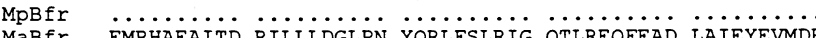
MaBAr BMBfr EMHHADKLIN RIIFFEGFPN LQTVSPLRIG QNVKEVLEAD LKGEYDARAS 101150 NGBFrA LKKGIKLCEE AQDYVTRDLM VAQLKDTEED HAHWLEQQLR LIELIGEGNY

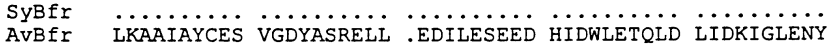
ECBfr LREAIGYADS VHDYVSRDMM . IEILRDEEG HIDWLETELD LIQKMGLQNY NgBfrB LLAAIATAEA QQDYVSRDLL .EKOKDTNEK HIDWLETQQE LIGKIGLPNY MIBfr LKPGIIMCRE KQDSTSAVLL .EKIVADEEE HIDYLETQLA LMGQLGEELY MaBfr LKPAIILCRE KQDSTTATLF .EQIVADEEK HIDYLETQLE LMDKLGVEY

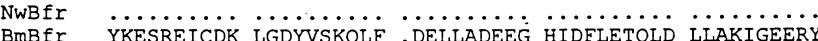

\begin{tabular}{|c|c|c|}
\hline 15 & & 16 \\
\hline$g B f r A$ & YQSQL ...... & .. \\
\hline $\begin{array}{l}\text { SyBfr } \\
\text { AvBfy }\end{array}$ & LQSQMDE. . & \\
\hline $\mathrm{EcBfr}$ & LQAQIREEG & \\
\hline $\mathrm{NgBf}$ rB & LQTAAQED. . & \\
\hline $\begin{array}{l}\text { MiBfr } \\
\text { MpBfr }\end{array}$ & SÄQCVSRPPS & \\
\hline $\begin{array}{l}\text { MpBfr } \\
\text { MaBfr }\end{array}$ & תמתיתום & \\
\hline $\begin{array}{l}\text { MaBfr } \\
\text { NwBfr }\end{array}$ & & \\
\hline & NAAP & \\
\hline
\end{tabular}

Fig. 5. Comparison of the deduced amino acid sequence of $N$. gonorrhoeae Bfr to other bacterial Bfrs. From top to bottom, the sequences presented are Bfrs from: $N$. gonorrhoeae (NgBfrA and NgBfrB), Synechocystis PCC 6308 (SyBfr), A. vinelandii (AvBfr), E. coli (EcBfr), M. leprae (MlBfr), M. paratuberculosis (MpBfr), M. avium (MaBfr), Nitrobacter winogradskyi (NwBfr) and B. melitensis (BmBfr). O, Putative ferroxidase-centre residues; $\boldsymbol{\nabla}$, methionine, haem-iron axial ligand.

either a ferritin or a Bfr homologue (Stiefel \& Watt, 1979; Moore et al., 1986; Kurokwa et al., 1989; Brooks et al., 1991; Rocha et al., 1992; Laulhère et al., 1993; Cristina et al., 1994; Inglis et al., 1994; Denoel et al., 1995; Evans et al., 1995; Penfold et al., 1996). However, the presence of both ferritin and Bfr has been reported in E. coli (Yariv et al., 1981; Izuhara et al., 1991) and Helicobacter pylori (Doig et al., 1993; Evans et al., 1995). It is not clear why relatively few bacteria possess both types of iron-storage proteins and what advantage this apparent redundancy has. In vitro data indicate that the rate at which iron is incorporated into apoferritin is approximately fivefold faster than into apoBfr, suggesting that ferritin might compete for iron in vivo more efficiently than Bfr (Andrews et al., 1993). We cannot rule out the possibility that the two biochemically and genetically different iron-storage proteins might have other specific or essential functions. For example, E. coli $\mathrm{Bfr}$ is also known as cytochrome $b_{1}$ and may additionally function as an electron-storage molecule (Smith et al., 1988). We have been unable to identify a potential ferritin homologue in $N$. gonorrhoeae by homology searches comparing the sequences of the E. coli and Haemophilus influenzae ferritin against the gonococcal (University of Oklahoma, N. gonorrhoeae strain FA1090) and meningococcal (The Sanger Center, Neisseria meningitidis serogroup A strain Z2491) genome databases. Alternatively, the gonococcus may have a ferritin gene that has little homology to those of E. coli or H. influenzae.

The homology of the amino acid sequences of gonococcal BfrA and BfrB to those of other Bfrs (Andrews et al., 1989; Kurokwa et al., 1989; Brooks et al., 1991; Grossman et al., 1992; Laulhère et al., 1993; Inglis et al., 1994; Denoel et al., 1995) for which full-length or partial sequences are available is shown in Fig. 5. Gonococcal BfrA and BfrB shared $39.7 \%$ identity. The percentage identity compared to other bacterial Bfrs ranged from $39.5 \%$ to $59 \cdot 6 \%$ for $\mathrm{BfrA}$, and from $41 \cdot 6 \%$ to $62.2 \%$ for BfrB. A seven amino acid motif consisting of Glu-18, -51, -94, -127, His-54, -130 and Tyr-25, which constitutes the ferroxidase centre (Andrews et al., 1991; Brun et al., 1995) and is associated with the binuclear metal-binding site, was fully conserved in BfrA (Fig. 5); however, only four of these seven residues were conserved in BfrB. Conversely, the methionine residue (Met-52), which provides the axial ligand for haem binding (Grossman et al., 1992; Cheesman et al., 1993), was conserved only in BfrB. These data demonstrate that the structure and function of Bfr are conserved among prokaryotes and suggest that both subunits are required to form a functional Bfr, with $\mathrm{Bfr} A$ providing the ferroxidase centre and BfrB the haembinding ligand. Interestingly, the seven amino acids which constitute the ferroxidase centre were conserved in E. coli ferritin but only five were retained in E. coli Bfr (Andrews et al., 1991, 1992). It has been suggested that the ferritin and Bfr of E. coli are the bacterial counterparts of the mammalian H-rich and L-rich ferritins with respective roles in short-term iron flux and long-term iron storage (Andrews et al., 1993). It is not clear whether gonococcal Bfr comprises equal molar ratios of the $A$ and $B$ subunits, or whether different Bfr subunits associate to form a Bfr that is either BfrA-rich or BfrBrich. However, the absence of iron-specific staining of Bfr by Ferrozine in the F62BfrB $\Omega$ mutant (data not shown) suggests that BfrA subunit alone can not form a functional iron-storage protein.

Based on X-ray crystallographic data, the structure of $E$. coli Bfr was shown to consist of 24 identical subunits that are assembled into a compact spherical protein shell containing approximately 12 haem groups per 24 subunits, with each haem bound in a pocket formed by the interface between a pair of symmetry-related subunits (Frolow et al., 1994). A stoichiometry of one haem per four subunits has been found in the Bfr from the cyanobacterium Synechocystis PCC6803 (Laulhère et al., 1993) and three to nine haem groups per 24 subunits in the Bfr from $P$. aeruginosa (Kadir \& Moore, 1990). We have yet to determine the number of haem groups 
per subunit in the gonococcal Bfr. However, it is likely that this value is less than 12 since only $\mathrm{BfrB}$ contains the essential methionine residue for haem binding.

Eukaryotic ferritins function by buffering the free-iron concentration in the cells, thus protecting cells from harmful iron-catalysed oxidative damage (Harrison \& Arosio, 1996). Similarly, a ferritin homologue from Campylobacter jejuni was recently reported to contribute to protection against oxidative stress (Wai et al., 1996). We investigated the role of the gonococcal Bfr in protecting against oxidative stress by insertionally inactivating $\mathrm{BfrB}$ and examining the sensitivity of a BfrB-deficient mutant to hydrogen peroxide and paraquat. The growth of the BfrB-deficient mutant of $N$. gonorrboeae was less than that of the parent strain under both iron-sufficient and iron-limiting conditions, suggesting that Bfr plays a role in iron storage. In addition, the $\mathrm{BfrB}$-deficient mutant was more sensitive to $\mathrm{H}_{2} \mathrm{O}_{2}$ and paraquat than the parent strain, suggesting that the accumulation of intracellular free iron caused by the absence of $\mathrm{BfrB}$ may lead to hypersensitivity to $\mathrm{H}_{2} \mathrm{O}_{2}$. Furthermore, BfrA alone was not capable of protecting the cell from oxidative injury.

A ferritin- and Bfr-deficient double mutant of E. coli grew poorly under iron-limited conditions (Simon Andrews, personal communication), suggesting the possibility of another internal iron pool. In our study, insertional inactivation of $\mathrm{BfrB}$ was not lethal to the growth of the gonococcus and provides further support for an internal iron pool. However, questions remain as to how this iron pool interacts with iron-storage or ironrequiring proteins. Although ferritins and Bfrs are involved in iron storage and in protection against oxidative stress, the exact role of ferritin and Bfr in iron metabolism has yet to be elucidated since the intracellular levels of these proteins present are considered too low to serve as major iron-storage compounds (Braun, 1997).

\section{ACKNOWLEDGEMENTS}

We would like to thank Dr Simon Andrews of University of Sheffield, UK for providing the polyclonal antiserum to E. coli Bfr; Ms Tamara Crews of the Biotechnology Core Facility at Centers for Disease Control, USA, for performing the Nterminal amino acid sequence analysis; and Dr Bernard Beall, Division of Bacterial and Mycotic Diseases, Centers for Disease Control, USA, for helpful suggestions.

\section{REFERENCES}

Andrews, S. C., Harrison, P. M. \& Guest, J. R. (1989). Cloning, sequencing, and mapping of the bacterioferritin gene $(b f r)$ of Escherichia coli K-12. J Bacteriol 171, 3940-3947.

Andrews, S. C., Smith, J. M. A., Yewdall, S. J., Guest, J. R. \& Harrison, P. M. (1991). Bacterioferritins and ferritins are distantly related in evolution: conservation of ferroxidase-center residues. FEBS Lett 293, 164-168.

Andrews, S. C., Arosio, P., Bottke, W. \& 7 other authors (1992). Structure, function, and evolution of ferritins. J Inorg Biochem 47, 161-174.

Andrews, S. C., Smith, J. M. A., Hawkins, C., Williams, J. M.,
Harrison, P. M. \& Guest, J. R. (1993). Overproduction, purification and characterization of the bacterioferritin of Escherichia coli and a C-terminal extended variant. Eur J Biochem 213, 329-338.

Braun, V. (1997). Avoidance of iron toxicity through regulation of bacterial iron transport. Biol Chem 378, 779-786.

Briat, J.-F. (1992). Iron assimilation and storage in prokaryotes. $J$ Gen Microbiol 138, 2475-2483.

Brooks, B. W., Martin Young, N., Watson, D. C., Robertson, R. H., Sugden, E. A., Nielsen, K. H. \& Becker, S. A. W. E. (1991). Mycobacterium paratuberculosis antigen $\mathrm{D}$ : characterization and evidence that it is a bacterioferritin. J Clin Microbiol 29, 1652-1658.

Brun, N. E., Andrews, S. C., Guest, J. R., Harrison, P. M., Moore, G. R. \& Thomson, A. J. (1995). Identification of the ferroxidase center of Escherichia coli bacterioferritin. Biochem J 312, 385-392.

Cheesman, M. R., Brun, N. E., Kadir, F. H. \& 7 other authors (1993). Haem and non-haem iron sites in Escherichia coli bacterioferritin: spectroscopic and model building studies. Biochem J 292, 47-56.

Chung, M. C. M. (1985). A specific iron stain for iron-binding proteins in polyacrylamide gels: application to transferrin and lactoferrin. Anal Biochem 148, 498-502.

Cristina, M., Pessolani, V., Smith, D. R., Rivoire, B., McCormick, J., Hefta, S. A., Cole, S. T. \& Brennan, P. J. (1994). Purification, characterization, gene sequence, and significance of a bacterioferritin from Mycobacterium leprae. J Exp Med 180, 319-327.

Denoel, P. A., Zygmunt, M. S., Weynaants, V., Tibor, A., Lichtfouse, B., Briffeuil, P., Limet, J. N. \& Letesson, J.-J. (1995). Cloning and sequencing of the bacterioferritin gene of Brucella melitensis 16M strain. FEBS Lett 361, 238-242.

Doig, P., Austin, J. W. \& Trust, T. J. (1993). The Helicobacter pylori 19.6-kilodalton protein is an iron-containing protein resembling ferritin. J Bacteriol 175, 557-560.

Dunford, H. B. (1987). Free radicals in iron-containing systems. Free Radic Biol Med 3, 405-421.

Evans, D. J., Jr, Evans, D. G., Lampert, H. C. \& Nakano, H. (1995). Identification of four new prokaryotic bacterioferritins, from Helicobacter pylori, Anabaena variabilis, Bacillus subtilis and Treponema pallidum, by analysis of gene sequences. Gene 153, 123-127.

Flitter, R. W., Rowley, D. A. \& Halliwell, B. (1983). Iron oxides in acid drainage environments and their association with bacteria. Chem Geol 74, 321-330.

Ford, G. C., Harrison, P. M., Rice, D. W., Smith, J. M. A., Treffry, A., White, J. L. \& Yariv, J. (1984). Ferritin: design and formation of an iron-storage molecule. Philos Trans $R$ Soc Lond Ser B Biol Sci 304, 551-565.

Frolow, F., Kalb, A. J. \& Yariv, J. (1994). Structure of a unique twofold symmetric heme-binding site. Struct Biol 1, 453-460.

Genco, C. A. \& Desai, P. J. (1996). Iron acquisition in the pathogenic Neisseria. Trends Microbiol 4, 179-184.

Grossman, M. J., Hinton, S. M., Minak-Bernero, V., Slaughter, C. \& Stiefel, E. I. (1992). Unification of the ferritin family of proteins. Proc Natl Acad Sci USA 89, 2419-2423.

Haber, F. \& Weiss, J. (1934). The catalytic decomposition of hydrogen peroxide by iron salts. Proc R Soc Ser A 147, 332-333.

Halliwell, B. \& Gutteridge, J. M. G. (1984). Oxygen toxicity, oxygen radicals, transition metals and disease. Biochem J 219, $1-12$.

Harker, A. R. \& Wullstein, L. H. (1985). Evidence for two non- 
identical subunits of bacterioferritin from Azotobacter vinelandii. J Bacteriol 162, 651-655.

Harrison, P. M. \& Arosio, P. (1996). The ferritins: molecular properties, iron storage function and cellular regulation. Biochim Biophys Acta 1275, 161-203.

Hudson, A. J., Andrews, S. C., Hawkins, C., Williams, J. M., Izuhara, M., Meldrum, F. C., Mann, S., Harrison, P. M. \& Guest, J. R. (1993). Overproduction, purification and characterization of the Escherichia coli ferritin. Eur J Biochem 218, 985-995.

Inglis, N. F., Stevenson, K., Hosie, A. H. F. \& Sharp, J. M. (1994). Complete sequence of the gene encoding the bacterioferritin subunit of Mycobacterium avium subspecies silvaticum. Gene 150, 205-206.

Izuhara, M., Takamune, K. \& Takata, M. (1991). Cloning and sequencing of an Escherichia coli K12 gene which encodes a polypeptide having similarity to the human ferritin $\mathrm{H}$ subunit. Mol Gen Genet 225, 510-513.

Kadir, F. H. A. \& Moore, G. R. (1990). Bacterial ferritin contains 24 haem groups. FEBS Lett 271, 141-143.

Klausner, R. D., Rouault, T. A. \& Harford, J. B. (1993). Regulating the fate of mRNA: the control of cellular iron metabolism. Cell 72, 19-28.

Kurokwa, T., Fukumori, Y. \& Yamanaka, T. (1989). Nitrobacter winogradskyi cytochrome $b$-559: a nonhaem iron-containing cytochrome related to bacterioferritin. Biochim Biophys Acta 976, 135-139.

Laulhère, J.-P., Labourè, A.-M., Van Wuytswinkel, O., Gagnon, J. \& Briat, J. -F. (1993). Purification, characterization and function of bacterioferritin from the cyanobacterium Synechocystis P. C. C. 6803. Biochem J 281, 785-793.

Mietzner, T. G., Luginbuhl, G. H., Sandstrom, E. C. \& Morse, S. A. (1984). Identification of an iron-regulated 37,000-dalton protein in the cell envelope of Neisseria gonorrhoeae. Infect Immun 45, 410-416.

Moore, G. R., Mann, S. \& Bannister, J. V. (1986). Isolation and properties of the complex nonheme-iron-containing cytochrome $b_{557}$ (bacterioferritin) from Pseudomonas aeruginosa. J Inorg Biochem 28, 329-336.

Moore, G. R., Kadir, F. H. A., Al-Massad, F. K., Brun, N. E., Thomson, A. J., Greenwood, C., Keen, J. F. \& Findlay, J. B. C. (1994). Structural heterogeneity of Pseudomonas aeruginosa bacterioferritin. Biochem J 304, 493-497.
Penfold, C. N., Ringeling, P. L., Davy, S. L., Moore, G. R., McEwan, A. G. \& Spiro, S. (1996). Isolation, characterization and expression of the bacterioferritin gene of Rhodobacter capsulatus. FEMS Microbiol Lett 139, 143-148.

Rocha, E. R., Andrews, S. C., Keen, J. N. \& Brock, L. H. (1992). Isolation of a ferritin from Bacteroides fragilis. FEMS Microbiol Lett 95, 207-212.

Sanger, F., Nicklen, S. \& Coulson, A. R. (1977). DNA sequencing with chain-terminating inhibitors. Proc Natl Acad Sci USA 74, 5463-5467.

Shyamala, V. \& Ames, G. (1989). Genome walking by singlespecific-primer polymerase chain reaction: SSP-PCR. Gene 84, 1-8.

Smith, J. M. A., Quirk, A. V., Plank, R. W. H., Diffin, F. M., Ford, G. C. \& Harrison, P. M. (1988). The identity of Escherichia coli bacterioferritin and cytochrome $b_{1}$. Biochem J 255, 737-740.

Stiefel, E. I. \& Watt, G. D. (1979). Azotobacter cytochrome $b_{557.5}$ is a bacterioferritin. Nature 279, 81-83.

Theil, E. C. (1987). Ferritin: structure, gene regulation, and cellular function in animals, plants, and microorganisms. Annu Rev Biochem 56, 289-315.

Touati, D., Jacques, M., Tardat, B., Buchard, L. \& Despied, S. (1995). Lethal oxidative damage and mutagenesis are generated by iron in fur mutants of Escherichia coli: protective role of superoxide dismutase. J Bacteriol 177, 2305-2314.

Wai, S. N., Takata, T., Takada, A., Hamasaki, N. \& Amako, K. (1995). Purification and characterization of ferritin from Campylobacter jejuni. Arch Microbiol 164, 1-6.

Wai, S. N., Nakayama, K., Umene, K., Moriya, T. \& Amako, K. (1996). Construction of a ferritin-deficient mutant of Campylobacter jejuni: contribution of ferritin to iron storage and protection against oxidative stress. Mol Microbiol 20, 1127-1134.

Wooldridge, K. G. \& Williams, P. H. (1993). Iron uptake mechanisms of pathogenic bacteria. FEMS Microbiol Rev 12, 325-348.

Yariv, J., Kalb, A. J., Serling, R., Bauminger, E. R., Cohen, S. G. \& Ofer, S. (1981). The composition and the structure of bacterioferritin of Escherichia coli. Biochem J 197, 171-175.

Received 1 March 1999; revised 18 May 1999; accepted 7 June 1999. 